\title{
Can cetuximab affect paraneoplastic myopathy?
}

\section{Eleni Galani · Anastasios Bonakis •}

Christos Christodoulou · George Klouvas •

Angeliki Drougou $\cdot$ Dimostenis Skarlos

Published online: 15 February 2009

(C) Springer Science+Business Media, LLC. 2009

\section{Erratum to: J Neurooncol}

\section{DOI 10.1007/s11060-009-9795-6}

The fifth author's name was misrepresented in the original publication. The correct name is listed in this erratum.

The online version of the original article can be found under doi: 10.1007/s11060-009-9795-6.

E. Galani · C. Christodoulou - G. Klouvas · D. Skarlos Second Oncology Department, Metropolitan Hospital, Ethn. Makariou 9, N. Faliro, Athens 18547, Greece

A. Bonakis ( $\square)$

Egenition Hospital, Neurological Department, University of Athens, Vasilissis Sofias Av. 72, Athens PC 11528, Greece e-mail: bonakistasos@yahoo.com

\section{A. Drougou}

Department of Histopathology, Red Cross Hospital, Erithrou

Staurou 1, Athens, Greece 